\title{
ENERGY PERFORMANCE OF OFFICE BUILDINGS IN GHANA
}

\author{
C. Koranteng \\ Department of Architecture, KNUST, Kumasi, Ghana \\ Email: christiankoranteng@yahoo.co.uk
}

\begin{abstract}
The parametrical measures that could improve the thermal performance of a sample of five existing buildings in Kumasi, Ghana were explored through a simulation application. These buildings are representative of the majority of existing low-rise office buildings in Kumasi and house different functions (university offices, private companies, municipal offices, etc.). The applied cooling systems typically involve split air-conditioning units. The simulation models were calibrated using indoor and external environmental conditions measured over a period of 12 months. This process led to a consistency of the simulation results which demonstrate that the use of efficient windows and natural ventilation can improve the buildings' energy performance. Explicitly, combined scenarios of efficient windows, natural ventilation, attic floor insulation and efficient electrical lighting resulted in a significant reduction (between 25 and $45 \%$ ) of the buildings' cooling loads.
\end{abstract}

Keywords: Energy, Efficient, Simulation, Improve, Cooling Load

\section{INTRODUCTION}

The world's energy crisis in 1973 and the inability of developing countries to guarantee the supply of energy have triggered studies into the sustainable use of energy. The world's reserves of crude oil are being used up rapidly and this has resulted in the increase of oil prices. The high oil price has a negative effect on the economies of developing and developed countries. The way forward is to look at sustainable and efficient means in the design of buildings and use of our natural resources. The application of simulation at the early stages of design could help as a decision support tool in testing design alternatives and in the validation of building designs on their performance. Designers should make the right decisions from the start and verify them before proceeding to the detailing stage. Statistically, about $20 \%$ of the decisions made at the early design stage affect about $80 \%$ of later decisions (Mourshed and Keane, 2003). Against this background, and due to the increase in green house gas emissions, the European Union Council Directive 93/76 required member states to develop and implement energy certifications for buildings (Szokolay, 2005). Now, the implemented directive has made it possible in using simulation as 


\section{Koranteng}

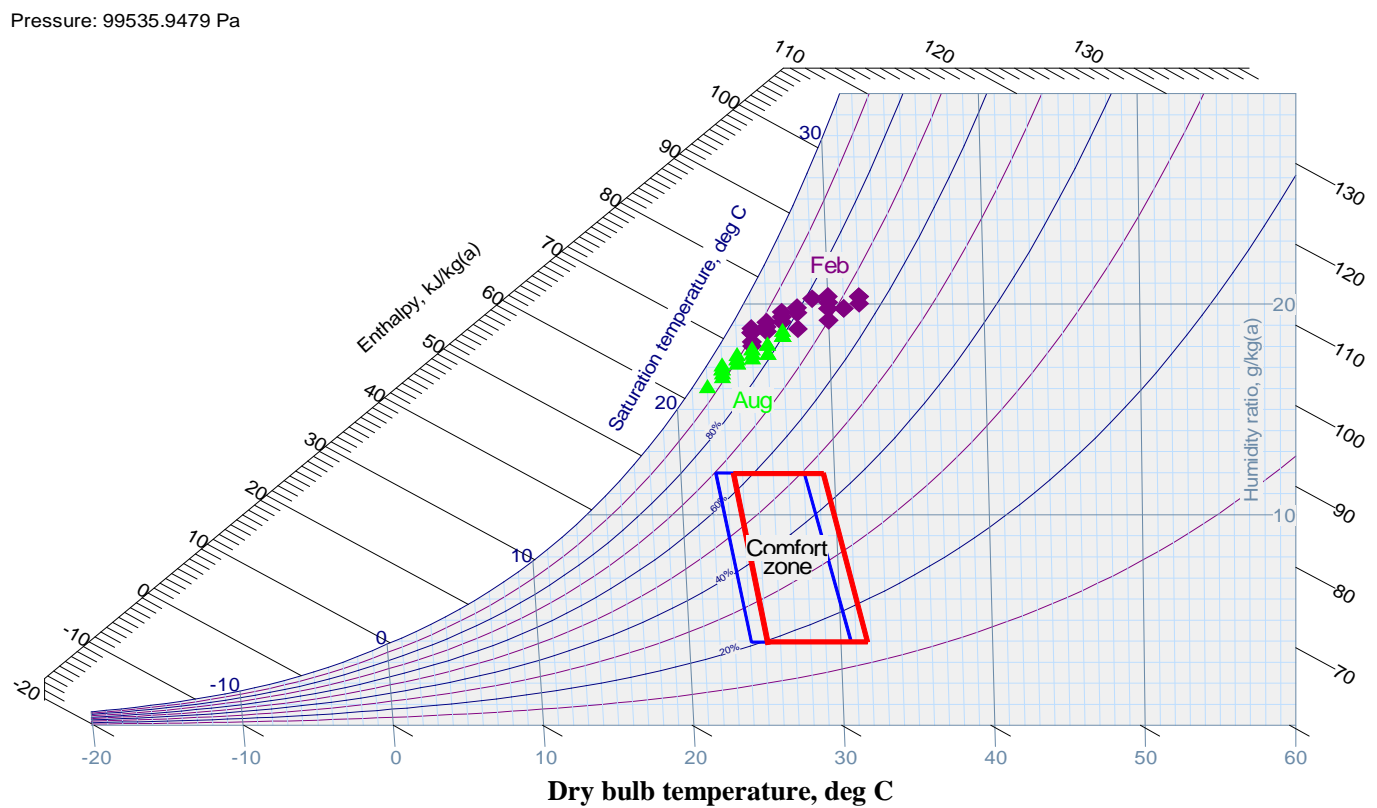

Fig.1: Mean hourly temperature and relative humidity values in Kumasi for representative days in the months of February and August (based on data generated via Meteotest (2008)

a tool in design decision making pertaining to energy-efficient buildings.

In view of the regional climatic characteristics of West Africa, energy requirements for cooling of office buildings in the region represent an increasing predicament for both Ghana's environment as well as its economy. Fig. 1 illustrates the mean hourly temperature and relative humidity values in Kumasi for representative days in the months of February and August (plotted on psychrometric chart (Cytsoft, 2008)).

The increasing demand for energy is among other factors, caused by the numerous newly constructed air-conditioned commercial buildings, especially in the metropolitan areas of Accra and Kumasi. The supply of energy has however not been able to meet its demand. According to the Energy Commission Ghana report (ECG, 2007), energy consumption of households increased from $26 \%$ in 2000 to $37 \%$ in 2005. Within the same period, energy con- sumption of the commercial sector actually doubled, that is from $7 \%$ to $14 \%$. In 1990 , Ghana had a surplus of electricity of 3,545 GWh (Gigawatt hours) and in 2004; a deficit of $203 \mathrm{GWh}$ was recorded. This upward trend of increasing demand for energy culminated in the load shedding exercise in the year 2006/2007.

Furthermore, most building designs are neither supported by a detailed analysis and evaluation of thermally relevant features nor by considerations about orientation, envelope, glazing ratio, shading devices, and thermal mass. Thus, design decision making is not sufficiently informed by pertinent expertise pertaining to energy-efficient building design methods and technologies.

In this context, the research presented in this paper is concerned with the following objectives:

a) Long-term monitoring of the thermal conditions in (and energy performance of) a selected number of office buildings in $\mathrm{Ku}-$ 
masi, Ghana.

b) Generation of calibrated simulation model of these office buildings.

c) Simulation-based exploration of design options toward a general reduction of cooling requirements in office buildings in Ghana.

\section{APPROACH}

Five office buildings (College of Architecture and Planning Administration Block (CAP), Centre for Cooperative Research (KCR), Angel Administration Centre (ANG), Royal Plaza (ROY) and Community Development Centre (DCD) in Kumasi were selected for the studies. The buildings have been given a three letter code and will be referred to as such. They house different organisations, are of various sizes and have a mix of occupants in different age groups (Table 1). Air temperature and relative humidity values were measured both inside (in a number of office rooms in each building) and outside the buildings over a period of 12 months.

Table 1: Overview of the selected office buildings with function, net floor area (in $\mathbf{~ m}^{2}$ ) and thermal controls

\begin{tabular}{llll}
\hline Building & Function & $\begin{array}{l}\text { Floor } \\
\text { Area }\end{array}$ & $\begin{array}{l}\text { Thermal } \\
\text { Controls }\end{array}$ \\
\hline CAP & University & 795 & $\begin{array}{l}\text { Mixed } \\
\text { mode }\end{array}$ \\
KCR & NGO & 1100 & $\begin{array}{l}\text { Air- } \\
\text { conditioned }\end{array}$ \\
ANG & Private & 365 & $\begin{array}{l}\text { Air condi- } \\
\text { tioned } \\
\text { ROY }\end{array}$ \\
$\begin{array}{l}\text { Construc- } \\
\text { tion com- } \\
\text { pany }\end{array}$ & 1740 & $\begin{array}{l}\text { Air condi- } \\
\text { tioned }\end{array}$ \\
& $\begin{array}{l}\text { Community } \\
\text { DCD }\end{array}$ & 280 & $\begin{array}{l}\text { Naturally } \\
\text { ventilated }\end{array}$ \\
\hline
\end{tabular}

With the aid of data loggers (Ocr, 2008) air temperatures and relative humidity values were measured in 15 offices, with a recording interval of 10 minutes. Furthermore, five sensors were mounted in the immediate vicinity of the buildings to record the outdoor environmental conditions. The accuracy of the respective sensors is given below (Table 2).

Table 2: Accuracy of the sensors (Hobos)

\begin{tabular}{lll}
\hline Sensor & Range & Error \\
\hline Air Temperature & -20 to $70^{\circ} \mathrm{c}$ & $\pm 0.4^{\mathrm{oC}}$ \\
Relative humidity & 5 to $95 \%$ & $\pm 3 \%$ \\
& & \\
\hline
\end{tabular}

Source: OCR (2008)

These measurements were necessary, since hourly weather data from the Kumasi meteorological office were not available. A weather file for Kumasi was also generated using Meteotest (2008). The data recordings started in September 2007 and ended in August 2008. The gathered data were screened, processed and analysed with the aid of a range of software programs (e.g. Microsoft excel, meteonorm, hoboware pro and psychrometric chart 2.16). The buildings were eventually modelled in a numeric simulation tool (EDSL, 2008) and calibrated by identifying segments of a synthetic weather file for Kumasi (generated via Meteotest (2008)) that matched our own measurements of outdoor conditions. Indoor air temperatures were then simulated using the above mentioned weather file segments and compared with the measured indoor air temperatures. Finally, a parametric study of thermal improvement scenarios (concerning glazing and shading, ventilation alternatives, thermal mass, efficient lighting) that could reduce cooling loads was carried out and the need for extensive active devices for air-conditioning were investigated. Information regarding the various scenarios considered for the simulations is summarized in Table 3 and 4. Table 3 provides the base case scenarios for the five buildings. Table 4 refers only to deviations from the respective base case (BC). 


\section{Koranteng}

Table 3: Overview of base case simulation scenarios

\begin{tabular}{|c|c|c|}
\hline Code & Scenario & Description \\
\hline $\mathrm{BC} 1$ & $\begin{array}{l}\text { Base case } \\
\text { CAP }\end{array}$ & $\begin{array}{l}\mathrm{U}_{\text {walls }}=0.4 \mathrm{~W} \cdot \mathrm{m}^{-2} \mathrm{~K}^{-1} \\
\mathrm{U}_{\text {window }}=5.8 \mathrm{~W} \cdot \mathrm{m}^{-2} \cdot \mathrm{K}^{-1} \\
\mathrm{~g}_{\text {window }}=0.82 \\
\text { Day/night } \mathrm{ACH}=1 / 0.5 \mathrm{~h}^{-1} \\
\text { Lighting load }=6 \mathrm{~W} \cdot \mathrm{m}^{-2} \\
\text { floors carpeted, no attic space }\end{array}$ \\
\hline $\mathrm{BC} 2$ & $\begin{array}{l}\text { Base case } \\
\mathrm{KCR}, \mathrm{ANG}, \mathrm{DCD}\end{array}$ & $\begin{array}{l}\text { Similar to } \mathrm{BC} 1 \text {, but attic space with: } \\
\mathrm{U}_{\text {attic floor }}=3.4 \mathrm{~W} \cdot \mathrm{m}^{-2} \mathrm{~K}^{-1} \\
\mathrm{U}_{\text {window }}=2.7 \mathrm{~W} \cdot \mathrm{m}^{-2} \cdot \mathrm{K}^{-1} \\
\mathrm{~g}_{\text {window }}=0.49 \\
\text { floors carpeted, no attic space }\end{array}$ \\
\hline $\mathrm{BC} 3$ & $\begin{array}{l}\text { Base case } \\
\text { ROY }\end{array}$ & $\begin{array}{l}\text { Similar to } \mathrm{BC} 1 \text {, but: } \mathrm{U}_{\text {window }}=5.5 \mathrm{~W} \cdot \mathrm{m}^{-2} \cdot \mathrm{K}^{-1}, \mathrm{~g}_{\text {window }} \\
=0.66 \\
\text { floors carpeted, no attic space }\end{array}$ \\
\hline
\end{tabular}

Source: Construction database of the building designer in Tas (EDSL, 2008)

Table 4: Overview of simulated improvement scenarios

\begin{tabular}{|c|c|c|}
\hline Code & Scenario & Description \\
\hline IWA & Improved wall insulation & $\mathrm{U}_{\text {walls }}=0.4 \mathrm{~W} \cdot \mathrm{m}^{-2} \mathrm{~K}^{-1}$ \\
\hline IWI & Improved windows & $\begin{array}{l}\mathrm{U}_{\text {window }}=1.8 \mathrm{~W} \cdot \mathrm{m}^{-2} \cdot \mathrm{K}^{-1} \\
\mathrm{~g}_{\text {window }}=0.29\end{array}$ \\
\hline IAT & $\begin{array}{l}\text { Improved attic } \\
\text { fl. insulation }\end{array}$ & $\begin{array}{l}\text { Similar to BC1, but: } \\
\mathrm{U}_{\text {attic floor }}=0.4 \mathrm{~W} \cdot \mathrm{m}^{-2} \cdot \mathrm{K}^{-1}\end{array}$ \\
\hline TMA & Thermal mass & Floors carpeted removed \\
\hline NVE & Night ventilation & Day/Night $\mathrm{ACH}=1 / 10 \mathrm{~h}^{-1}$ \\
\hline NVT & TMA+NVE & See TMA and NVE \\
\hline ELI & Efficient electric lighting & Lighting load $=2 \mathrm{~W} \cdot \mathrm{M}^{-2}$ \\
\hline $\mathrm{C} 11$ & $\begin{array}{l}\text { Combined improvements CAP, } \\
\text { ROY }\end{array}$ & $\begin{array}{l}\mathrm{U}_{\text {window }}=1.8 \mathrm{~W} \cdot \mathrm{m}^{-2} \cdot \mathrm{K}^{-1}, \\
\mathrm{~g}_{\text {window }}=0.29 ; \text { Day } / \mathrm{Night} \mathrm{ACH}=1 / 10 \mathrm{~h}^{-1}, \text { Lighting } \\
\text { load }=2 \mathrm{~W} \cdot \mathrm{m}^{-2}\end{array}$ \\
\hline $\mathrm{C} 12$ & $\begin{array}{l}\text { Combined improvements KCR, } \\
\text { ANG, DCD }\end{array}$ & $\begin{array}{l}\mathrm{U}_{\text {attic floor }}=0.4 \mathrm{~W} \cdot \mathrm{m}^{-2} \cdot \mathrm{K}^{-1}: \mathrm{U}_{\text {window }}=1.8 ; \text { Lighting load } \\
=2 \mathrm{~W} \cdot \mathrm{m}^{-2}\end{array}$ \\
\hline
\end{tabular}

Source: Construction database of the building designer in Tas (EDSL, 2008) 
Energy Performance of Office Buildings... 118

\section{RESULTS}

(i) Measured external air temperature values

Fig. 2 shows the comparison of the outdoor temperature measurements "DL" (averaged over the office locations) with an average temperature "MET" obtained as the mean of maximum and minimum temperatures recorded by Kumasi's weather station. These results suggest a good agreement between our measurements and those from Kumasi's official weather station.

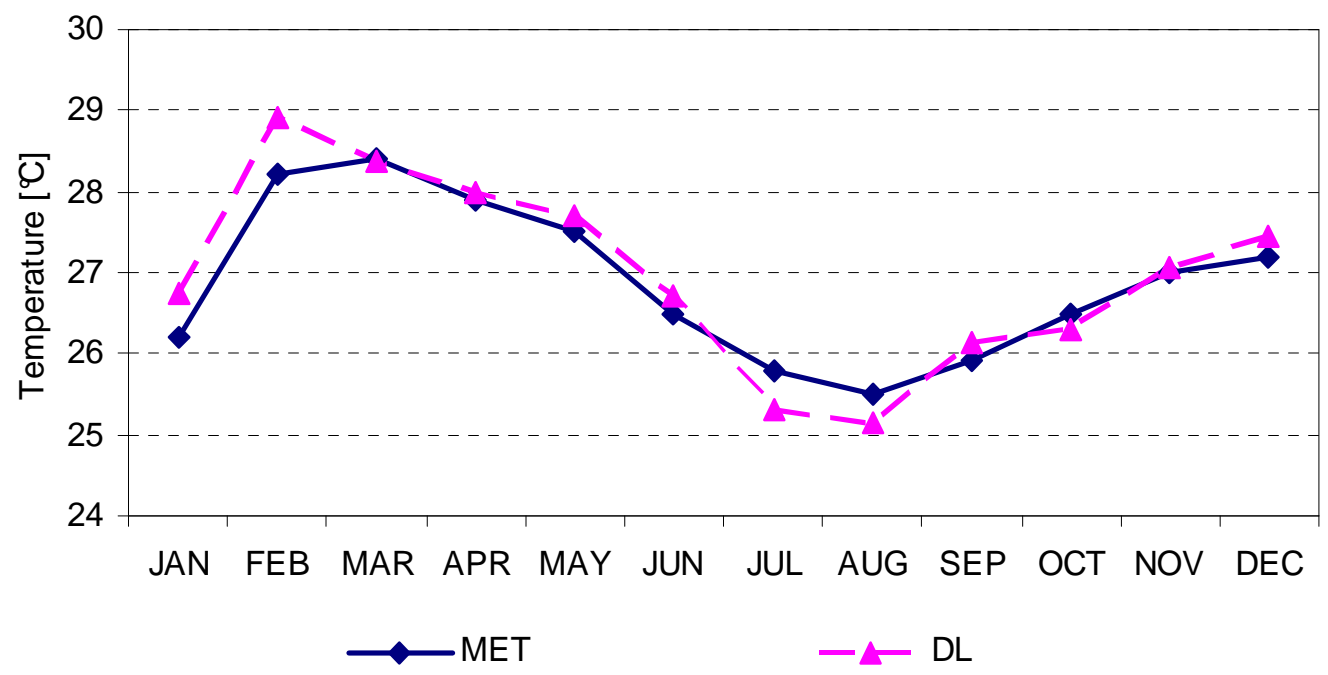

Fig.2: Comparison of mean outdoor temperature measurements at office locations (DL) with Kumasi weather station data (MET)

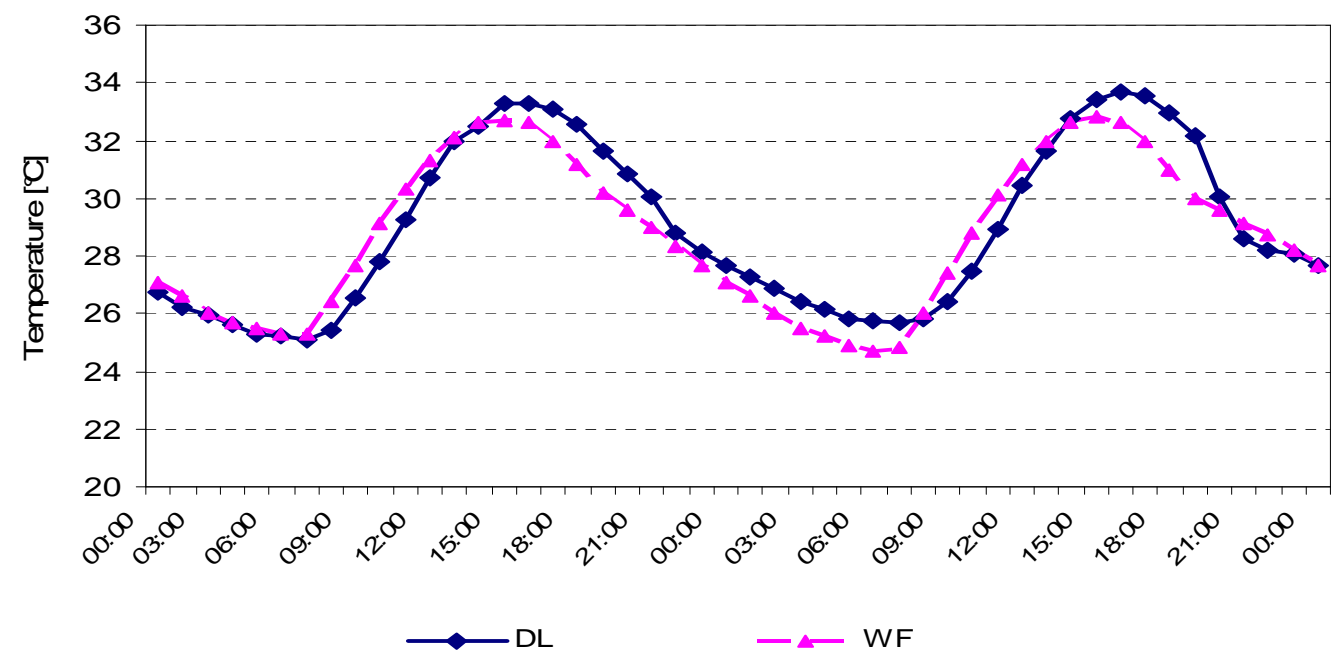

Fig.3: Outdoor air temperatures from weather file segments (WF) used for simulation calibration in comparison with measurements (DL) at building location (KCR) 


\section{Koranteng}

(ii) Weather file versus measured data As mentioned earlier, simulation model calibration was performed using segments of a standard weather file with a good fit to our local measurements. To illustrate this point, Figs. 3 to 5 show samples of time intervals where the weather file data (WF) and our measurements at building sites (DL) showed a relatively good agreement.

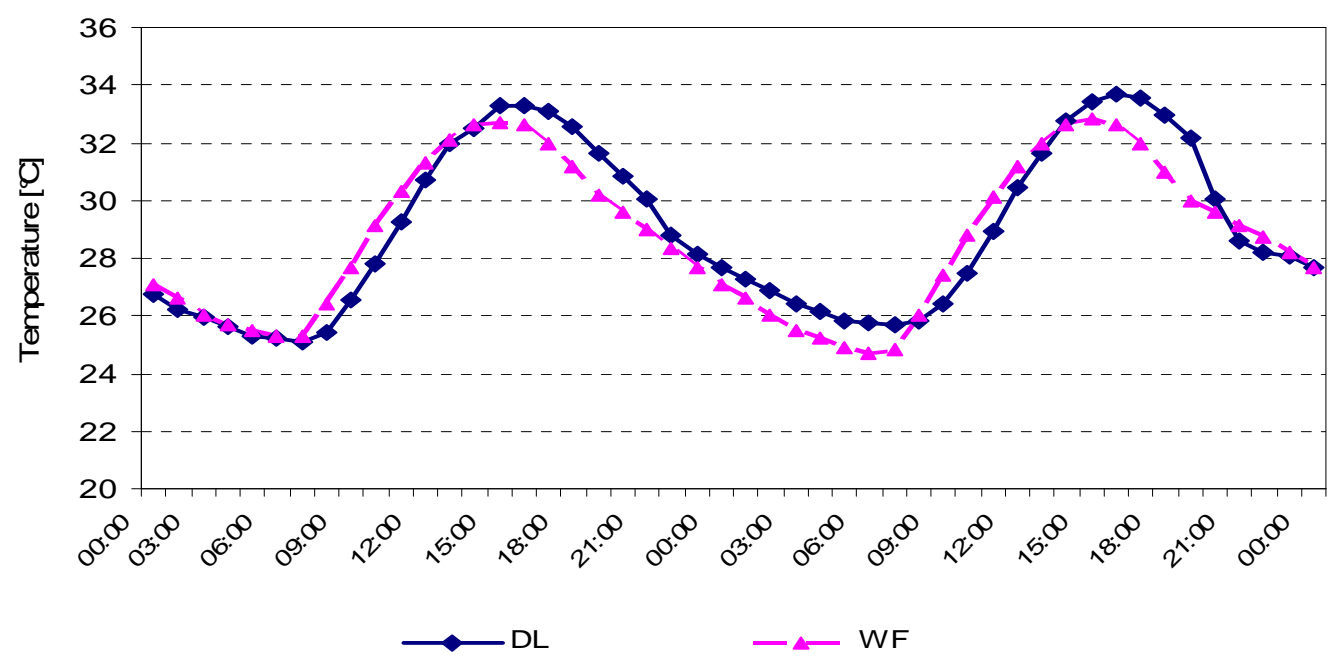

Fig.4: Outdoor air temperatures from weather file segments (WF) used for simulation calibration in comparison with measurements (DL) at building location (ANG)

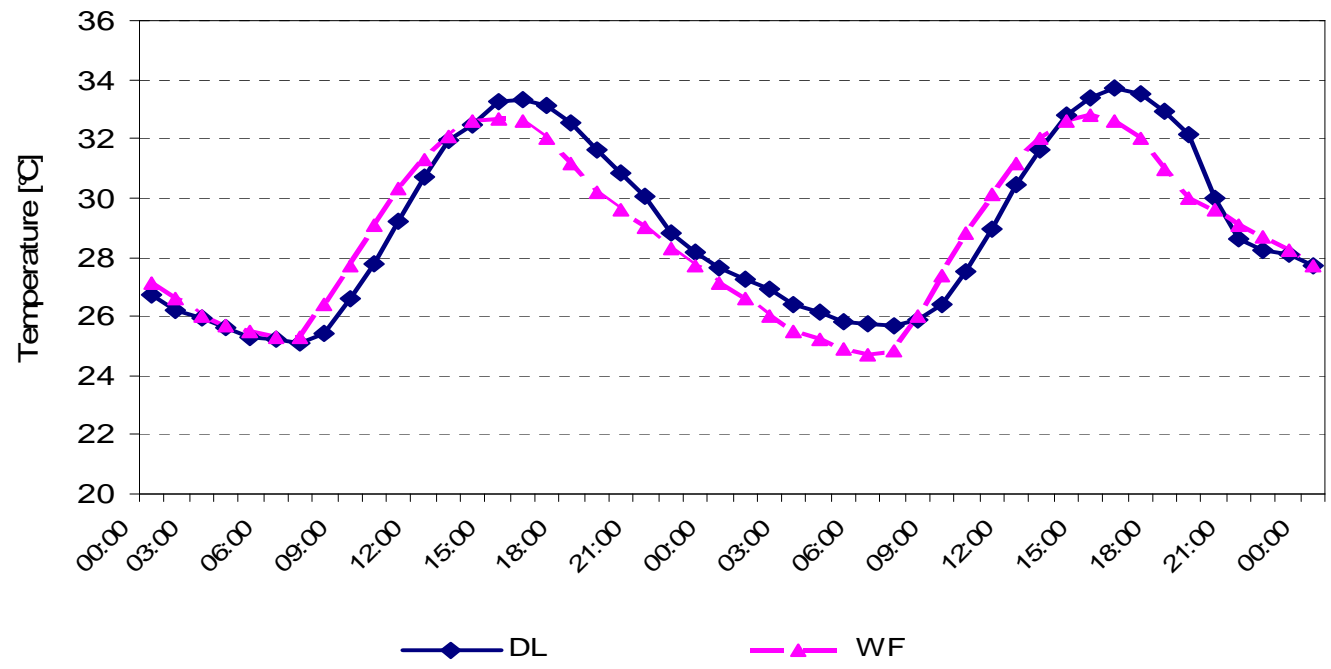

Fig.5: Outdoor air temperatures from weather file segments (WF) used for simulation calibration in comparison with measurements (DL) at building location (DCD) 
Energy Performance of Office Buildings... 120

(iii) Comparison of measurements and simulations

Predictions of the calibrated simulation models compared well with the measured values. To illustrate this, Figs. 6 and 7 provide examples of measured versus simulated indoor air temperatures in buildings CAP and KCR.

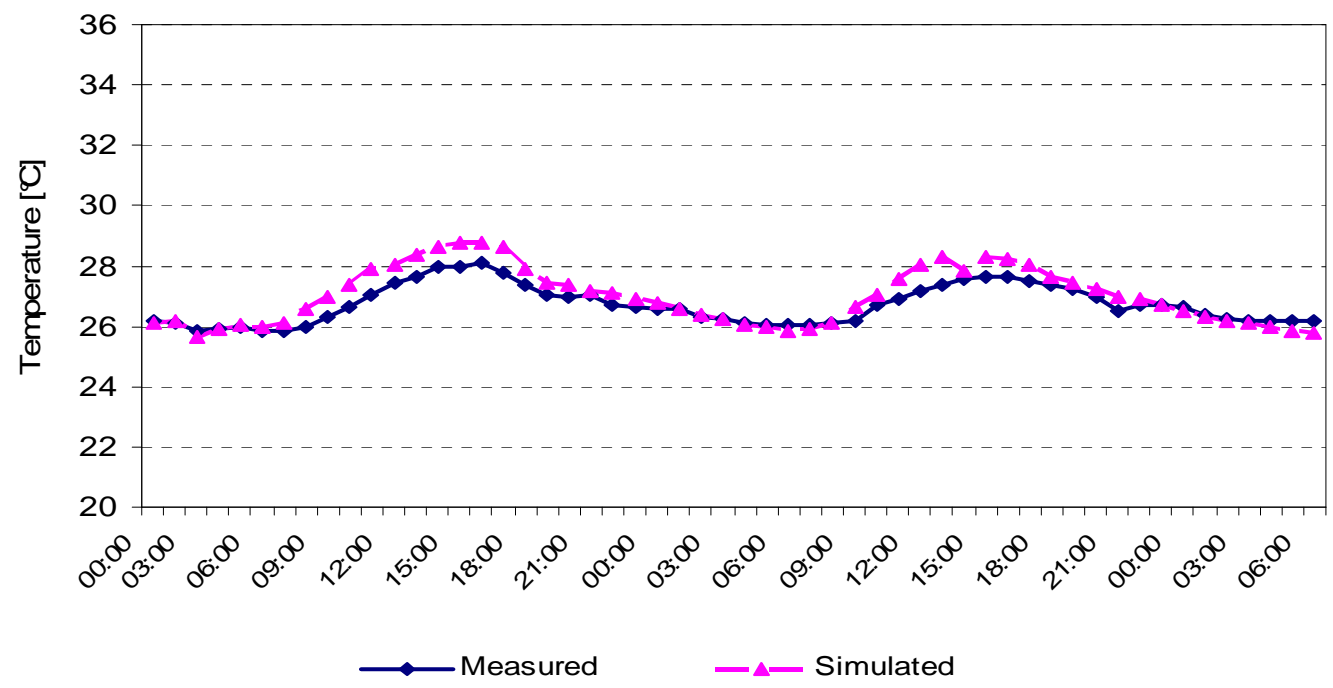

Fig.6: Measured versus simulation indoor air temperatures in CAP

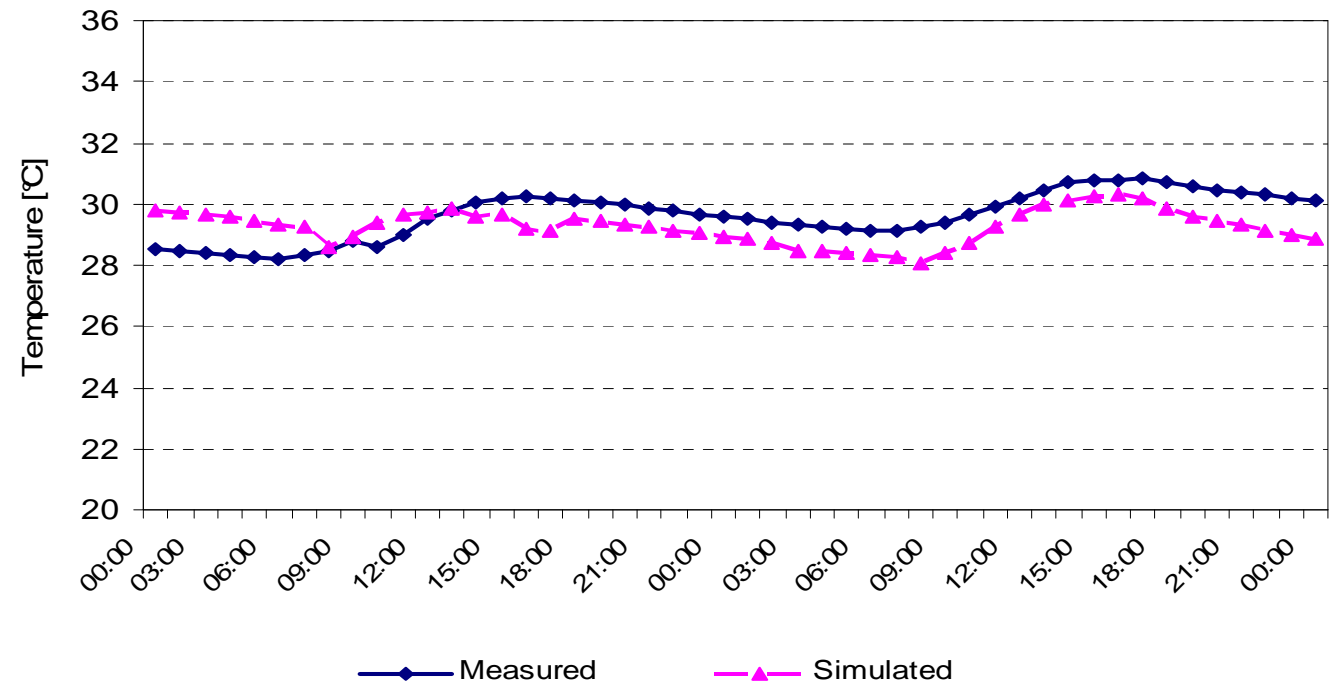

Fig.7: Measured versus simulation indoor air temperatures in KCR 


\section{Koranteng}

(iv) Results of parametric simulations

For each building, Figs. 8 to 12 show the simulated thermal loads for a number of scenarios.
In addition, Fig. 13 illustrates the simulated cooling loads (in percentage of the respective base cases) for all buildings and for selected scenarios.

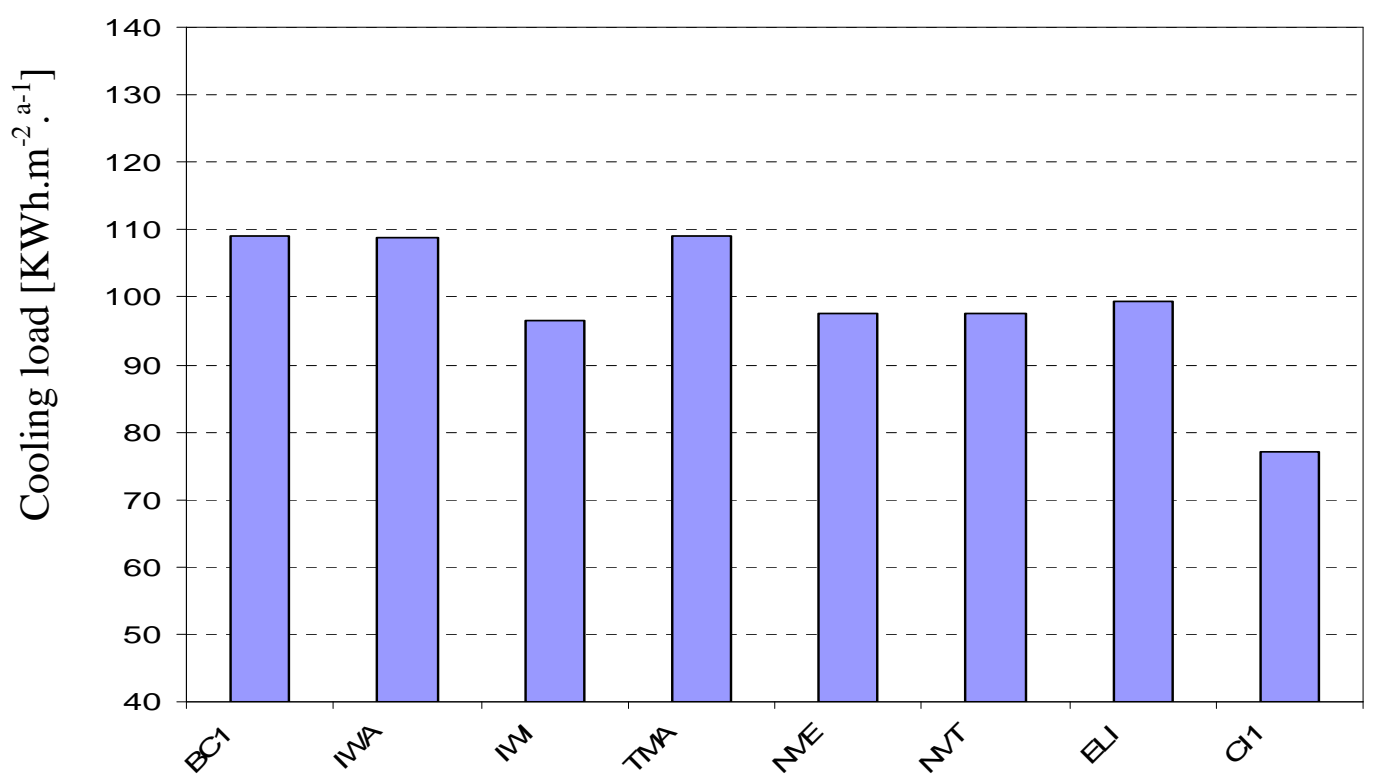

Fig.8: Simulated cooling loads (CAP) for different scenarios (see Tables 3 and 4)

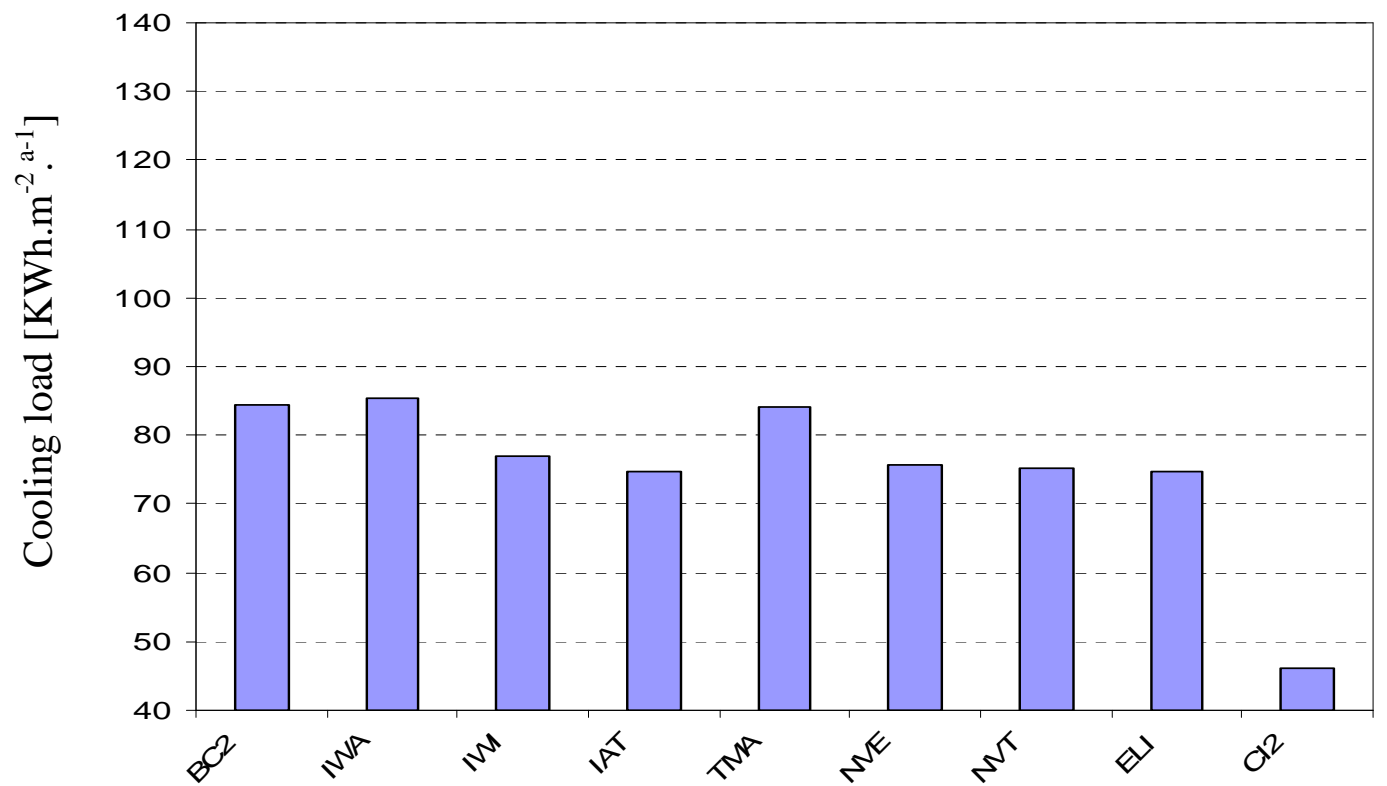

Fig.9: Simulated cooling loads (KCR) for different scenarios (see Tables 3 and 4) 


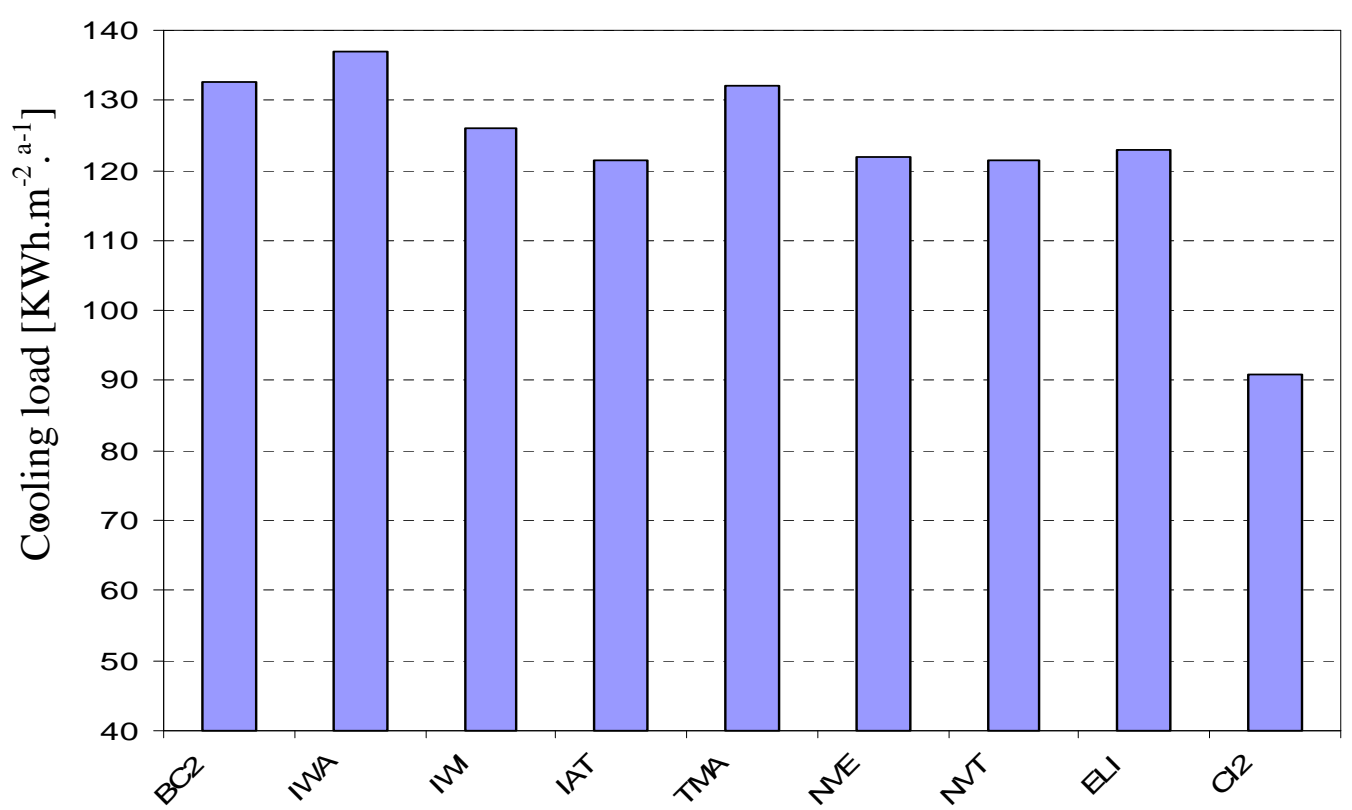

Fig.10: Simulated cooling loads (ANG) for different scenarios (see Tables 3 and 4)

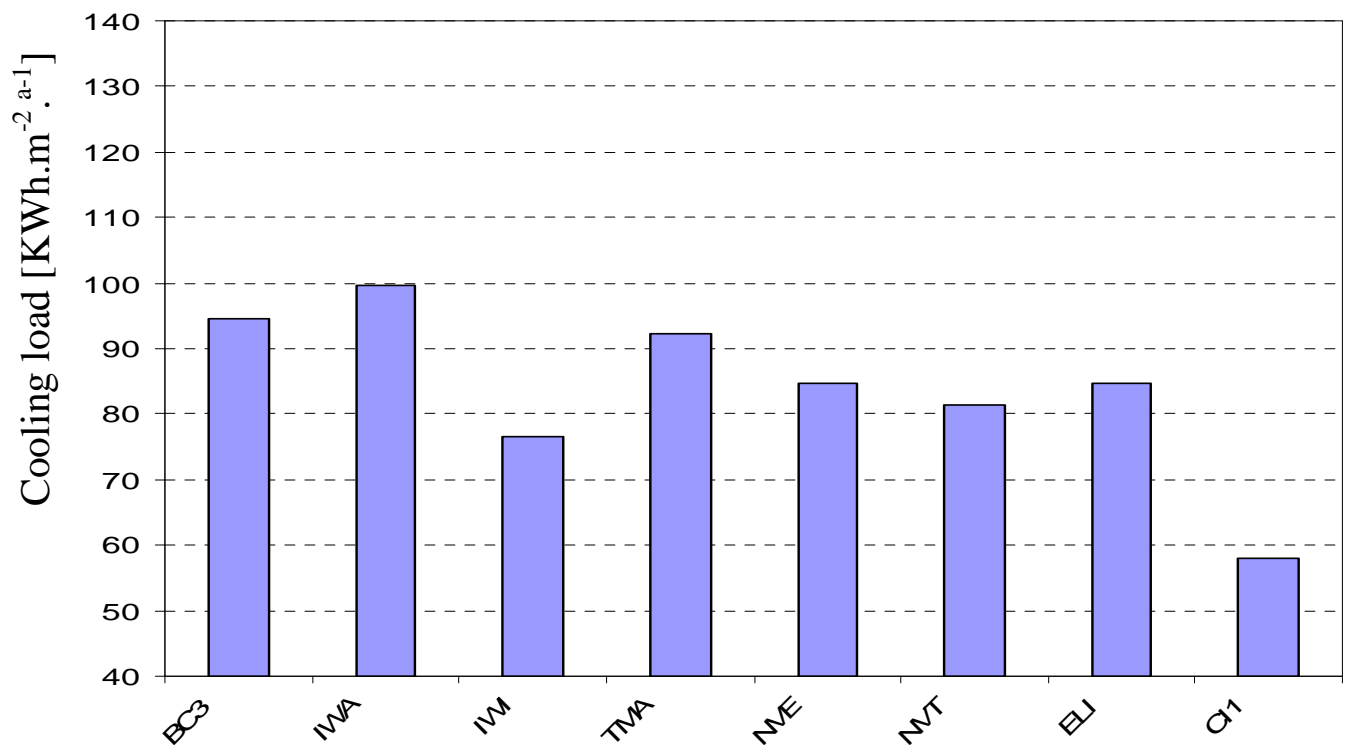

Fig.11: Simulated cooling loads (ROY) for different scenarios (see Tables 3 and 4) 


\section{Koranteng}

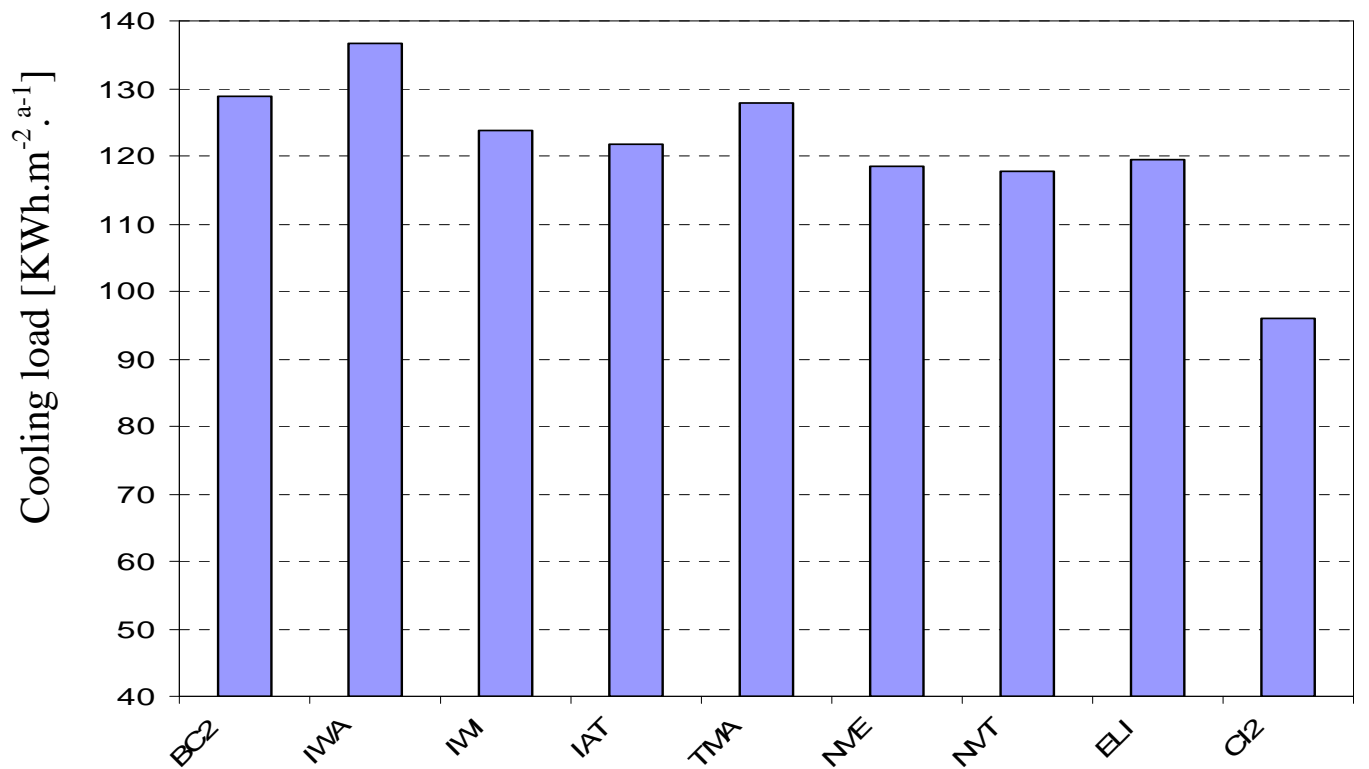

Fig.12: Simulated cooling loads (DCD) for different scenarios (see Tables 3 and 4)

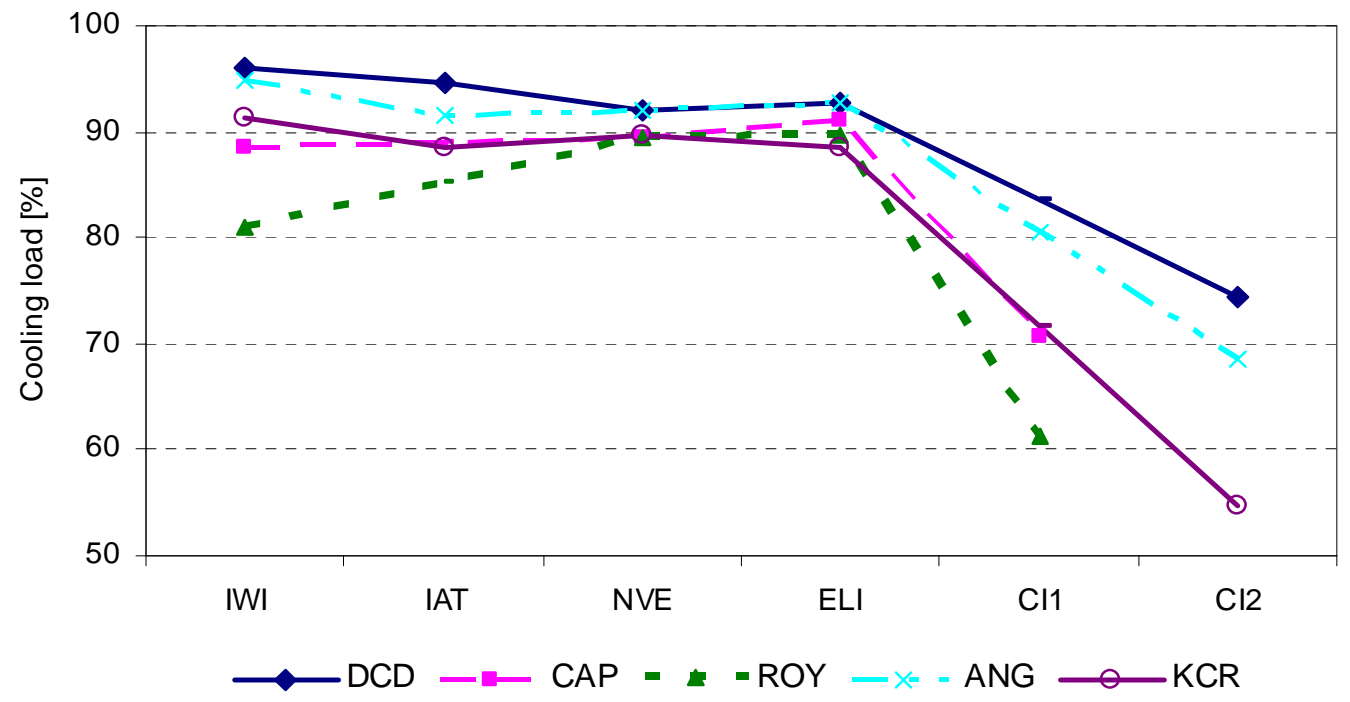

Fig.13: Simulated cooling loads (in percentage of the respective base cases) for all buildings and for selected scenarios (see Tables 3 and 4) 


\section{DISCUSSION}

\section{CAP building}

The simulated cooling load for the base case (BC1) was 109 KWh.m-2. a $^{-1}$ (Kilowatt hours per square meter and annum), Fig. 8. The building is a rectangular block, oriented towards the north-south and shaded by a veranda on the elongated sides.

The tested alternative of improving the wall quality through the addition of $10 \mathrm{~cm}$ insulation resulted in an insignificantly reduced cooling load to $99.7 \%$. This could be due to the shaded walls that were well protected from direct and reflected solar radiation through the veranda (Lechner, 2001). Designers are advised to make use of the positive effects of the natural environment, transform the environmental burden and use the building as a basis for its defence before the implementation of active control devices (Heerwagen, 2004).

By using a more efficient type of windows with a better shading coefficient (0.29), cooling loads reduced to $88.5 \%$. The effect was that only $29 \%$ of radiation gains could be transmitted through the glass as compared to the $82 \%$ at the base case scenario.

Thermal mass was however insignificant. This was achieved by removing the carpet of the floors to expose the mass to thermal gains. The result could be related to the small diurnal difference (often less than 5 Kelvin), which was relatively low to have a positive effect.

Night ventilation had a reduction effect of $11 \%$ as compared to the base case scenario. However, when combined with thermal mass, no significant change was recorded. The stored cool energy was rapidly used up, since the effect was minimal as a result of the diurnal difference stated above.

The use of efficient lighting reduced the loads by $9 \%$. This was due to the reductions in lighting gains having a positive effect on cooling loads.
All the improvements combined resulted in cooling load reductions of $29 \%$. This result is significant and was achieved through improved and efficient building elements, and sustainable design principles of orientation and shading.

\section{KCR building}

The base case load of the L-shaped building had a cooling load of $84 \mathrm{KWh} \cdot \mathrm{m}^{-2} \cdot \mathrm{a}^{-1}$. The improvement to the wall by adding insulation increased the loads by $1 \%$ (Fig. 9), although a reduction of $1 \%$ was calculated at CAP. This increment gives an indication of the heat gained and generated within the building, and not being able to escape through the building fabric due to the better construction element.

A 9\% reduction in cooling load was calculated by improving the windows. Efficient and shaded windows seem to contribute positively to reductions in cooling loads.

The attic floor was improved by adding $10 \mathrm{~cm}$ of insulation and this resulted in $11 \%$ reductions in cooling load. Attic spaces are usually characterized by very high temperatures and insulation could reduce the conductive heat gains into the working spaces, which resulted in less energy use (Szokolay, 2004).

The effect of thermal mass was insignificant; reductions of only $0.3 \%$ have been recorded. However, $10 \%$ reductions were recorded by making use of the night ventilation. A further reduction of $0.4 \%$ was recorded when night ventilation was used in combination with the thermal mass. Again, the conditions of low diurnal change and wind velocities in the night could have rendered this principle useless (Stein and Reynolds, 2000).

About $11 \%$ reductions in cooling loads were calculated by reducing the lighting loads through the usage of efficient lights. According to Phillips (2004), even $20 \%$ of energy savings can be gained when efficient lights are used in conjunction with high frequency electronic control gear. 


\section{Koranteng}

All the combinations together produced a significant reduction of $45 \%$ in cooling loads (Fig. 9 and Table 4). The comparatively higher depth of the building block in combination with the form could also have contributed to these positive results (Hawkes, 1996).

\section{ANG building}

A cooling load of 133 KWh.m- ${ }^{2} \cdot a^{-1}$ was simulated for the base case scenario at the ANG building (Fig. 10). The office block in rectangular form was on the second floor of a building block with the elongated sides oriented towards the west.

There was an increase of $3 \%$ in cooling loads when the walls were improved with insulation. Thermal mass and thermal mass in combination with night ventilation did not bring about significant change as compared to the effect of night ventilation alone. This is in agreement with the view of Szokolay (2004), saying that the effect of mass cannot be fully relied on in warm and humid countries.

However, positive effects could be simulated for the improvements in windows, attic insulation, night ventilation and efficient lighting. All the simulated improvements resulted in a significant reduction of $31 \%$ cooling load (Fig. 13).

\section{ROY building}

The curtain wall building had an initial cooling load of $95 \mathrm{KWh} \cdot \mathrm{m}^{-2} \cdot \mathrm{a}^{-1}$. Improving the wall with insulation only increased the cooling loads by $5 \%$ (Fig. 11). It can therefore be concluded that the application of insulation to walls does not result in a positive change towards the reduction of cooling loads. This result is contrary to the recommendation by Lauber (2005) on the use of wall insulation in tropical countries.

A reduction in cooling load as high as $19 \%$ was simulated, and this significant value was as a result of the better shading coefficient of the glassing (Lechner, 2001). Possibly, more reductions could have been simulated if there had been external shading on the façade helping to reduce the direct, intense and reflected solar radiation (Chou, 2001). The energy penalty as against the almost $100 \%$ visual link to the external environment should be considered, especially at this stage of global uncertainties, both financially and on natural resources. Designing buildings with sealed windows and without reference to solar orientation, with high standards of comfort but without reference to operating costs, with the newest technology but without much sense of what tomorrow might bring must be reconsidered (Wagner et al., 1980).

Thermal mass reduced the cooling load by $2 \%$. This reduction could be caused by the open office landscape and less internal walls as compared to the other case studied buildings, since all of them recorded insignificant reductions of less than $1 \%$.

Reductions of $10 \%$ were recorded by making use of night ventilation. Night ventilation in combination with thermal mass reduced the loads further by $3 \%$. The minor reduction could be linked to the missing partitioning walls in the ROY building. As much as $10 \%$ reductions could be retrieved from the use of efficient lighting (Phillips, 2004).

A significant value of $39 \%$ was achieved when the improvements were combined (Fig. 11 and Table 4).

\section{DCD building}

The rectangular block, oriented towards the south east, had an initial cooling load of 129 KWh.m- ${ }^{2} \cdot \mathrm{a}^{-1}$. The alternative of using insulation rather increased the cooling loads by $6 \%$ (Fig. 12). Improved windows and attic insulation reduced the cooling loads by 4 and $5 \%$ respectively. There were few windows in the building and this resulted in the relatively lower improvements in cooling loads.

Less than $1 \%$ improvement was achieved by the use of thermal mass whereas $8 \%$ could be 
retrieved by using night ventilation. However, night ventilation in combination with thermal mass brought about an insignificant change in cooling load when compared to the effects of night ventilation alone. A further reduction of $7 \%$ in cooling load could be simulated by reducing the lighting gains through the use of efficient lights..

The total improvements from the positive combinations (CI2 in Table 4) resulted in a significant reduction of $25 \%$ in cooling load.

Further loads could have been achieved if attention had been given to sustainable design principles of form, orientation and shading (Prajapati 2006). Building designers are again advised to make use of the positive effects of the natural environment, transform the environmental burden and use the building as the basis of its defence before the implementation of active control devices (Heerwagen, 2004). According to Wagner et al. (1980), by orienting rectangular buildings with the correct aspect ratio (1:2.5), 50\% glassing and planting shaded tress all around, cooling loads of 30 and 25\% could be saved respectively. The effect of uncontrolled ventilation or leakage through cracks in the building envelope also leads to increased cooling loads (Carmody, 2007) and should therefore be avoided. In addition, other recommendations are sun protection and thermal insulation of the building shell, which has to be windproof and airtight (Lauber, 2005). However, thermal insulation of walls does not help to reduce cooling loads in the climatic context of Kumasi, Ghana, as suggested by Lauber (2005).

\section{CONCLUSION}

The result obtained from the calibrated simulation models warrants certain conclusions:

Improvement of the thermal insulation of the external walls did not produce a corresponding improvement in the energy performance of the buildings. This circumstance was due to the heat retaining effect of well insulated walls.
The improvement of the thermal insulation of the attic space floors clearly improves the thermal performance, due to the reduction of conductive heat flows from these typically overheated spaces.

Increased night-time natural ventilation improved the thermal performance of the buildings, albeit in a modest fashion. This is due to the rather small diurnal temperature range in Ghana: the night temperature does not drop sufficiently to effectively cool the building mass.

The simulation results demonstrate that some improvements to the building fabric and controls can bring about better performance. Specifically, combinations of improvement measures (such as efficient windows and electrical lighting, natural ventilation and attic insulation) have the potential to significantly reduce the buildings' cooling loads by 25 to $45 \%$ in the climatic context of Kumasi, Ghana.

\section{REFERENCES}

Carmody, J., Selkowitz, S., Arasteh, D. and Heschong, L. (2007). Residential Windows: A Guide to New Technologies and Energy Performance. Third Edition, W.W. Norton \& Company Ltd., New York, USA, pp. 46 - 48.

Chou, S.K. (2001). Seminar Proceedings, Energy Efficiency in Building Design: Building Energy Standard. Building and Construction Authority of Singapore, Singapore, (18 ${ }^{\text {th }}$ April 2001), paper 2 .

Cytsoft (2008). Psychrometric chart 2.16, www.cytsoft.com.

ECG (2007). Energy commission Ghana, National Energy Statistics - 2005, ECG, Accra, Ghana, pp. 25, 50.

EDSL (2008). A-TAS Version 8.5. Environmental Design Solutions Limited. 


\section{Koranteng}

www.edsl.net.

Hawkes, D. (1996). The Environmental Tradition - Studies in the Architecture of Environment. E and FN SPON, London, pp. 36 - 45

Heerwagen, D. (2004). Passive and Active Environmental Controls: Informing the Schematic Designing of Buildings. First Edition, McGraw Hill, New York, USA, pp. 2 - 5.

Lauber, W. (2005). Tropical Architecture. First Edition, Prestel Verlag, Munich, Germany, pp. $101-105$.

Lechner, N. (2001). Heating, Cooling, Light ing: Design Methods for Architects. Second Edition, John Wiley \& Sons, Inc., New York, USA, pp. 219 - 222, $237-239$.

Meteotest (2008). Meteonorm version 6.0. www.meteotest.ch.

Moursehed, M. K. and Keane, D. M. (2003). A Tool to Optimise the Environmental Design of Buildings. www.ucc.ie/ iruse/papersNew/ IB P S A 2003 Monjur.pdf.

Ocr (2008). Onset Computer Corporation, www.onsetcomp.com.

Phillips, D. (2004). Daylighting: Natural Light in Architecture. First Edition, Architectural Press, Oxford, United Kingdom, pp. 38.

Prajapati, J. (2006). Workshop Proceedings, Design Guidelines for Energy Efficient Buildings. Department of Energy Science and Engineering, Indian Institute of Technology, Bombay, (September 2006), pp. 12 - 21.

Stein, B. and Reynolds, J. S. (2000). Mechanical and Electrical Equipment for Buildings. Ninth Edition, John Wiley \& Sons, Inc., New York, USA, pp. 57 -58 .

Szokolay, S. (2004). Introduction to Architectural Science: The Basis of Sustain able Design. First Edition, Architectural Press, Oxford, pp. $42-43,68-$ $69,221-227$.

Wagner, W., Robinson, J. and Markert, P. (1980). Energy-Efficient Buildings. First Edition, McGraw-Hill Book Company, New York, USA, pp. 1 - 5, 8 . 